\title{
Aclidinium Bromide: Clinical Benefit in Patients with Moderate to Severe COPD
}

\author{
Charlotte Suppli Ulrik ${ }^{*}$
}

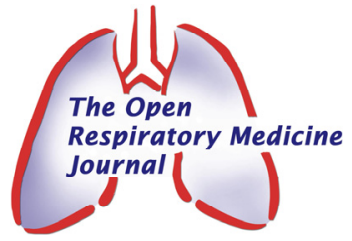

\section{Department of Respiratory Medicine, Hvidovre Hospital \& University of Copenhagen, Denmark}

\begin{abstract}
Background and Aim: Long-acting bronchodilators are the mainstay of pharmacological treatment for patients with chronic obstructive pulmonary disease (COPD). The aim of this review is to provide an overview of the clinical studies evaluating the safety and efficacy of inhaled aclidinium bromide, a novel long-acting anticholinergic bronchodilator, for the treatment of COPD.

Method: This systematic review explored the efficacy and safety of aclidinium bromide in comparison with placebo and other long-acting bronchodilators for treatment of moderate to severe COPD. Randomised controlled trials were identified through systematic searches of different databases of published trials.

Results: Ten trials (3.922 participants) were included. Aclidinium bromide appears to be a safe and well-tolerated longacting anti-cholinergic bronchodilator with a relatively fast onset of action. Compared with other long-acting bronchodilators, including tiotropium bromide, aclidinium bromide leads to at least similar clinically important improvements in level of $\mathrm{FEV}_{1}$, health status, use of rescue medication, and day-time dyspnea scores in patients suffering from moderate to severe COPD. With twice-daily dosing, aclidinium bromide may have clinically important effect on night-time symptom scores in COPD patients, but further studies are needed in order to permit valid conclusions with regard to this point. The effect of aclidinium bromide on exercise tolerance, as assessed by exercise endurance time, and dynamic hyperinflation in patients with moderate to severe COPD seems to be at least comparable to other long-acting bronchodilators, incl. tiotropium bromide and indacaterol. Aclidinium bromide might reduce the rate of exacerbations in COPD patients, but conclusions must await further long-term controlled trials.
\end{abstract}

Conclusion: Aclidinium bromide has effects on relevant COPD outcome measures, including level of FEV $\mathrm{F}_{1}$, similar to other long-acting bronchodilators, and therefore seems to have the potential for a significant role in the future management of moderate to severe COPD.

Keywords: COPD, aclidinium, long-acting antimuscarinic agents, long-acting, bronchodilators.

\section{INTRODUCTION}

The Global Initiative for Chronic Obstructive Pulmonary Disease (GOLD strategy document) recommends maintenance treatment with at least one long-acting bronchodilator for patients with moderate to severe COPD [1]. In general, bronchodilators provide the mainstay of pharmacological treatment of COPD $[1,2]$.

In COPD, long-acting bronchodilators help to prevent and control symptoms, reduce the frequency and severity of exacerbations, and improve health status and exercise performance $[1,3,4]$. Furthermore, inhaled long-acting bronchodilators, including $\beta_{2}$-agonists and muscarinic antagonists, reduce air trapping and improve emptying of the lungs, and by that reduce lung volumes, leading to an improvement in breathlessness and increasing exercise capacity $[1,3,5]$. Based on studies from recent years, longacting anticholinergic agents appear to be the most effective bronchodilators for the management of COPD $[1,2,6,7]$.

*Address correspondence to this author at the Department of Respiratory Medicine, 253 Hvidovre Hospital, Hvidovre Hospital, DK-2650 Hvidovre, Denmark; Tel: +45 3862 6089; Fax +45 4583 6331;

E-mail: csulrik@dadlnet.dk
Currently, the only long-acting anticholinergic bronchodilator marketed for the treatment of COPD is tiotropium bromide, but several others are in various stages of development, including aclidinium bromide.

The aim of this review is to provide an overview of the clinical studies evaluating the safety and efficacy of inhaled aclidinium bromide for the treatment of COPD

\section{MATERIAL AND METHODS}

The general principles of the Preferred Reporting Items for Systematic reviews and Meta-Analyses (PRISMA) guidelines $[8,9]$ were adopted to perform this review. A series of systematic searches were carried out, last updated October 2012, using the database PubMed, EMBASE, Cochrane Controlled Trials Register, and Clinical Trials.gov using the following algorithm of MeSH terms: Aclidinium bromide, indacaterol, QAB149, glycopyrronium bromide, NVA 237, formoterol, tiotropium, long-acting bronchodilators, and COPD, and the searches were repeated with these terms in combination with $\mathrm{FEV}_{1}$, hyperinflation, exercise capacity, dyspnoea, health status, quality of life and exacerbations in order to identify published studies. The search was limited to English-language articles. Clinical 
trials published solely in abstract form were excluded because the methods and results could not be fully assessed.

To be included, studies had to meet all the following criteria: 1) published in peer-reviewed journal, 2) randomised controlled trial, 2) inclusion of adults aged $>40$ years with stable moderate to severe COPD according to the Global Obstructive Lung Disease (GOLD) strategy document (1) or American Thoracic Society/European Respiratory Society (ATS/ERS) guideline criteria, 3) comparison of inhaled aclidinium bromide with placebo, tiotropium bromide, indacaterol, salmeterol, formoterol, or glycopyrronium bromide, and 4) report at least one of the following outcomes: onset of action, trough $\mathrm{FEV}_{1}$ (24 hours post-dosing) at the end of the treatment period, peak change in $\mathrm{FEV}_{1}$, inspiratory capacity, exercise capacity, health status assessed with the St. George Respiratory Questionnaire (SGRQ), use of rescue medication, symptom relief (assessed with the transitional dyspnoea index), and exacerbations.

A meta-analysis was not included in the present review, primarily due to the limited number of published clinical trials fulfilling the inclusion criteria.

\section{RESULTS}

Of the 114 potential relevant citations identified, 10 trials fulfilled the inclusion criteria (3.922 participants). Participants were stable, but symptomatic at baseline and fulfilled the spirometric criteria for moderate to severe COPD. All included studies were multicentre, randomised controlled trials sponsored by a single pharmaceutical company (Table 1). Three studies compared aclidinium bromide with tiotropium bromide (and placebo), six studies with placebo, and one study with formoterol.

Table 1. Characteristics of Included Aclidinium Bromide Studies in Patients with Moderate to Severe COPD

\begin{tabular}{|c|c|c|c|c|c|c|c|c|}
\hline Study & $\begin{array}{c}\text { Duration } \\
\text { (Weeks) }\end{array}$ & $\begin{array}{c}\text { No. of } \\
\text { Subjects }\end{array}$ & $\begin{array}{c}\text { Males } \\
(\%)\end{array}$ & $\begin{array}{l}\text { Mean } \\
\text { Age } \\
\text { (Years) }\end{array}$ & $\begin{array}{l}\text { Mean Baseline } \\
\text { FEV }_{1} \% \text { pred }\end{array}$ & $\begin{array}{c}\text { Smoking History } \\
\text { (Pack-Yrs) }\end{array}$ & Drug and Dose & Main Outcome \\
\hline Vestbo et al. [9] & - & 115 & 69 & 63 & 43 & 48 & $\begin{array}{c}\text { Acli\# } 200 \mu \mathrm{g} \\
\text { Tioto } 18 \mu \mathrm{g} \\
\text { Plac* }\end{array}$ & $\begin{array}{c}\text { Onset of } \\
\text { bronchodilation }\end{array}$ \\
\hline Jones et al. [10] & 52 & $\begin{array}{l}843 \\
804\end{array}$ & $\begin{array}{l}79 \\
62\end{array}$ & $\begin{array}{l}62 \\
65\end{array}$ & $\begin{array}{l}53 \\
50\end{array}$ & $\begin{array}{l}39 \\
58\end{array}$ & $\begin{array}{c}\text { Acli } \# 200 \mu \mathrm{g} \\
\text { Plac* }\end{array}$ & $\begin{array}{l}\text { Trough } \mathrm{FEV}_{1} \text { at } \\
\text { week } 12 \text { and } 28\end{array}$ \\
\hline Joos et al. [12] & - & 17 & 100 & 64 & 49 & 44 & $\begin{array}{c}\text { Acli\# } 100 \mu \mathrm{g} \\
\text { Acli\# } 300 \mu \mathrm{g} \\
\text { Acli\# } 900 \mu \mathrm{g} \\
\text { Plac* }\end{array}$ & $\begin{array}{l}\text { Area under the } \\
\text { FEV }_{1} \text { curve }\end{array}$ \\
\hline Chanez et al. [13] & 4 & 464 & 83 & 62 & 48 & 45 & $\begin{array}{c}\text { Acli\# } 25 \mu \mathrm{g} \\
\text { Acli\# } 50 \mu \mathrm{g} \\
\text { Acliø } 100 \mu \mathrm{g} \\
\text { Acli\# } 200 \mu \mathrm{g} \\
\text { Acli\# } 400 \mu \mathrm{g} \\
\text { Tiot } 18 \mu \mathrm{g} \\
\text { Plac* }\end{array}$ & $\begin{array}{c}\text { Trough } \mathrm{FEV}_{1} \text { on } \\
\text { day } 29\end{array}$ \\
\hline Singh et al. [14] & 1 & 79 & 59 & 61 & 54 & 51 & $\begin{array}{c}\text { Acli\# } 100 \mu \mathrm{g} \\
\text { Acli\# } 200 \mu \mathrm{g} \\
\text { Acli\# } 400 \mu \mathrm{g} \\
\text { Form\& } 12 \mu \mathrm{g} \\
\quad \text { Plac* }\end{array}$ & $\begin{array}{l}\text { Area under the } \\
\text { FEV }_{1} \text { curve }\end{array}$ \\
\hline Fuhr et al. [15] & 2 & 30 & 63 & 58 & 56 & 41 & $\begin{array}{c}\text { Acli\# } 400 \mu \mathrm{g} \\
\text { Tioto } 8 \mu \\
\text { Plac* }\end{array}$ & $\begin{array}{c}\text { Area under the } \\
\mathrm{FEV}_{1} \text { curve }(0- \\
12 / 12 \mathrm{~h})\end{array}$ \\
\hline Kerwin et al. [16] & 12 & 561 & 53 & 64 & 54 & 54 & $\begin{array}{c}\text { Acli\# } 200 \mu \mathrm{g} \\
\text { Acli\# } 400 \mu \mathrm{g} \\
\text { Plac* }\end{array}$ & Trough FEV $_{1}$ \\
\hline Jones et al. [17] & 24 & 828 & 67 & 62 & 53 & 40 & $\begin{array}{c}\text { Acli\# } 200 \mu \mathrm{g} \\
\text { Acli\# } 400 \mu \mathrm{g} \\
\text { Plac* }\end{array}$ & Trough FEV $_{1}$ \\
\hline Maltais et al. [18] & 6 & 181 & 58 & 65 & 51 & 55 & $\begin{array}{c}\text { Acli\# } 200 \mu \mathrm{g} \\
\text { Plac* }\end{array}$ & $\begin{array}{c}\text { Exercise } \\
\text { endurance time }\end{array}$ \\
\hline
\end{tabular}




\section{Onset of Action and Safety Profile}

Vestbo et al. [10] studied, in a double-blind, doubledummy, cross-over design, the percentage of patients with an increase in $\mathrm{FEV}_{1} \geq 10 \%$ above baseline at 30 minutes post dose. Significantly more patients reached the end-point with aclidinium and tiotropium $v s$ placebo (49.5\% and $51.8 \%$ vs $13.8 \% ; \quad \mathrm{p}<0.0001) ;$ and aclidinium and tiotropium significantly improved $\mathrm{FEV}_{1}$ compared with placebo at all measured points from 10 minutes to 3 hours post-dose. The rate of onset of bronchodilation of aclidinium is, based on the present study, at least as fast as for tiotropium.

The safety profile of aclidinium bromide was studied based on pooled data from ACCLAIM/COPD I and ACCLAIM /COPD II by Jones et al. [10]. The overall incidence of adverse events was similar in the aclidinium and placebo groups, apart from a higher frequency of dry mouth in the groups treated with aclidinium. In the clinical studies published so far cardiac and vascular disorders were reported at a similar frequency in the aclidinium and placebo groups $[11,12]$.

\section{FEV $_{1}$}

The study by Joos et al. [13] enrolled patients with an $\mathrm{FEV}_{1}<65 \%$ of predicted value and bronchodilator reversibility $>12 \%$ and $200 \mathrm{~mL}$. The mean area under the $\mathrm{FEV}_{1}$ curve (primaru outcome) over the 0-24 $\mathrm{h}$ time interval was $1.58 \mathrm{~L}$ for placebo, and $1.72 \mathrm{~L}, 1.79 \mathrm{~L}$, and $1.82 \mathrm{~L}$ for aclidinium 100, 300, $900 \mu \mathrm{g}$, respectively $(\mathrm{p}<0.001 v s$ placebo, all doses). The authors concluded that aclidinium bromide 100-900 $\mu \mathrm{g}$ produces sustained bronchodilatation over $24 \mathrm{~h}$ in patients with moderate to severe COPD. In keeping with this, the ACCLAIM/COPD I and ACCLAIM/COPD II published by Jones et al. [11] revealed a trough $\mathrm{FEV}_{1}$ at 12 and 28 weeks of aclidinium bromide versus $v s$ placebo of $61 \mathrm{ml}$ and $67 \mathrm{ml}$ (both $\mathrm{p}<0.001$ ), and 63 $\mathrm{ml}$ and $59 \mathrm{ml}$ (both $\mathrm{p}<0.001$ ), respectively, in the two studies.

Chanez et al. [14] aimed at establishing the optimal dose of aclidinium bromide in COPD patients with an $\mathrm{FEV}_{1}$ of 30 to $65 \%$ pred. Aclidinium bromide at doses of $200 \mu \mathrm{g}$ and 400 $\mu \mathrm{g}$ and tiotropium bromide were statistically significant more effective than placebo in increasing through $\mathrm{FEV}_{1}$ at day 29. Adjusted mean differences compared with placebo in through $\mathrm{FEV}_{1}$ for aclidinium were $148 \mathrm{ml}(200 \mu \mathrm{g})$ and 128 $\mathrm{ml}(400 \mu \mathrm{g})$, and for tiotropium $161 \mathrm{ml}$. In line with this Singh et al. [15] studied, in a double-blind, double-dummy, placebo- and active comparator controlled crossover design, the mean change from baseline in $\mathrm{FEV}_{1}$ normalised area under the curve (AUC) $)_{0-12}$ on day 7. After 7 days of treatment, aclidinium and formoterol produced statistically significant greater change from baseline in $\mathrm{FEV}_{1}$ normalised $\mathrm{AUC}_{0-12}$ vs placebo; and, furthermore, the study confirmed the twice-daily aclidinium dosing regimen and aclidinium $200 \mu \mathrm{g}$ and $400 \mu \mathrm{g}$ as suitable doses for further investigation. Furthermore, the study by Fuhr et al. [16] showed that aclidinium bromide $400 \mu \mathrm{g}$ twice-daily compared with placebo provided clinically meaningful in 24-h bronkodilatation that generally were comparable to the effect of tiotropium bromide, but with statistically significant differences in favour of aclidinium bromide observed in the night-time period.
In the ACCORD I/COPD study including COPD patients with a mean baseline $\mathrm{FEV}_{1}$ of 47 \%pred., Kerwin et al. [17] showed that Aclidinium bromide $200 \mu \mathrm{g}$ and $400 \mu \mathrm{g}$ significantly improved mean $(95 \% \mathrm{CI})$ trough $\mathrm{FEV}_{1}$, compared with placebo, by $86(45,127) \mathrm{ml}$ and $124(83,164)$ $\mathrm{ml}$, respectively, and peak $\mathrm{FEV}_{1}$ by $146(101,190) \mathrm{ml}$ and $192(148,236) \mathrm{ml}$, respectively $(\mathrm{p}<0.0001)$.

From the ATTAIN study of COPD patients with a mean baseline $\mathrm{FEV}_{1}$ of 53 \%pred, Jones et al. [18] reported a significant improvement from baseline with aclidinium 200 $\mu \mathrm{g}$ and $400 \mu \mathrm{g} v s$ placebo for trough $\mathrm{FEV}_{1}$ (99 and $128 \mathrm{ml}$; $\mathrm{p}<0.0001)$ and peak $\operatorname{FEV}_{1}$ (185 and $209 \mathrm{ml}$; $\left.<<0.0001\right)$. Furthermore, the observed improvement in peak $\mathrm{FEV}_{1}$ on day 1 was comparable with that on week 24 .

\section{Exercise Capacity and Hyperinflation}

Maltais et al. [19] investigated exercise capacity in COPD patients with a mean post-bronchodilator $\mathrm{FEV}_{1}$ approximately $50 \%$ pred, and functional residual capacity $\geq$ $120 \%$ pred. At screening, all patients underwent symptomlimited cycle ergometry with increasing work-load in $10 \mathrm{~W}$ increments in order to determine the maximum tolerated workload; and constant work rate cycling exercises at $75 \%$ of peak work rate were performed at baseline, day 1, week 3 , and week 6 (primary end-point). Patients treated with aclidinium had, compared with placebo, significantly greater improvement in exercise endurance time (mean \pm SE of 129 $\pm 31 \mathrm{~s}$ for aclidinium $v s 13 \pm 31 \mathrm{~s}$ for placebo). Furthermore, the study by Maltais et al. [19] also revealed a significant treatment difference from baseline in trough inspiratory capacity (IC) and IC/total lung capacity, and by that suggesting a beneficial effect on dynamic hyperinflation

\section{Health Status, Symptom Relief, and Use of Rescue Medication}

Chanez et al. [14] reported a decrease in the total St. George Respiratory Questionnaire (SGRQ) score, and by that improved, from baseline with all doses of aclidinium. The percentage of patients with meaningful improvement in SGRQ total score $\geq 4$ points from baseline ranged from $53 \%$ in the $400 \mu \mathrm{g}$ group to $64 \%$ in the $100 \mu \mathrm{g}$ group; the improvements in SGRQ score were mainly due to changes in the symptom and impact components. Data, however, on corresponding improvements among patients treated with placebo and tiotropium, and by that makes it extremely difficult to draw valid conclusions with regard to the effect on health status. Furthermore, statistically significant increases in Transition Dyspnoea Index (TDI) were also reported for aclidinium $100 \mu \mathrm{g}$ and $400 \mu \mathrm{g}$ compared with placebo, but no exact data were reported, including whether the minimal clinical significance were reached, and no statistically significant difference compared with placebo were observed in any treatment group in the magnitude of the effort component. Overall, there were no significant differences between active treatment and placebo in the mean number of days with self-reported symptoms of dyspnoea, cough, wheeze, sputum or daily doses of rescue salbutamol. In contrast to this, Singh et al. [15] reported that daily use of relief medication was lower with all doses of aclidinium and with formoterol compared with placebo; treatment difference in number of daily puffs of relief 
medication was up to -0.48 for aclidinium $(\mathrm{p}<0.05)$ and -0.67 for formoterol $(\mathrm{p}<0.05)$.

The ACCLAIM/COPD I study [11] showed that significantly more patients receiving aclidinium had an improvement in SGRQ total score $\geq 4$ units compared with placebo at all measured time points, although the percentage of patients achieving this improvement was $48 \%$ and $40 \%$, respectively for aclidinium and placebo, appears lower than in the study by Chanez et al. [14]. Furthermore, in the ACCLAIM/COPD II study [11], no significant difference in percentage of patients achieving an improvement in SGRQ total score $\geq 4$ units was found between aclidinium (39\%) and placebo $(33 \%)$ at week 52 . In line with this, the ACCLAIM/COPD I study [11] showed that compared with placebo significant more patients treated with aclidinium exceeded the minimal clinical important difference (MCID) for TDI focal score at 52 weeks (aclidinium 56\% vs placebo $38 \% ; p<0.0001$ ), whereas no significant difference in TDI focal score was found in the ACCLAIM/COPD II study, possibly due to the very high drop-out rate in the latter study. Overall, no general significant differences between aclidinium and placebo was observed in the two studies reported by Jones et al. [11] with regard to daily symptom scores or use of rescue medication. The ATTAIN study [18] showed a significant improvements in health status, assessed by SGRQ, daily use of relief medication, and TDI focal score in patients treated with aclidinium compared with placebo.

Fuhr et al. [16] reported a significant decline in use of relief medication with both aclidinium and tiotropium compared with placebo, with no significant difference between aclidinium and tiotropium. Furthermore, compared with placebo, aclidinium significantly reduced breathlessness $(\mathrm{p}=0.026)$ and cough $(\mathrm{p}=0.039)$; night-time COPD symptom score, assessed on a scale from 0 to 4 , were significantly reduced by aclidinium compared with placebo at day 15 $(p=0.049)$, whereas no significant change was observed with tiotropium [16]. In line with this, the study by Kerwin et al. [17] reported a significant reduction in frequency of nighttime symptoms, including breathlessness and wheezing, severity and impact of breathlessness and cough on nighttime activity, impact of breathlessness on early morning activity, and frequency of night-time awakenings.

\section{Exacerbations}

Jones et al. [10] reported from the ACCLAIM/COPD II study that fewer in the aclidinium group experienced a moderate (defined as treatment with antibiotics and/or systemic corticosteroid) or severe (defined as hospitalisation) exacerbation compared with those in the placebo group (33\% vs $40 \% ; \mathrm{p}=0.0046)$; and that aclidinium significantly delayed the time to first moderate or severe exacerbation. However, in the ACCLAIM/COPD I study [10], the proportion of patients having a moderate or severe exacerbation was similar in the aclidinium and placebo groups (27\% vs 26\%). The study by Kerwin et al. [17] observed a trend towards a reduction in moderate to severe COPD exacerbation rates with aclidinium compared with placebo, although the study was not powered to assess exacerbation frequency. The ATTAIN study [18] reported, compared with placebo, a lower rate of exacerbations in patients treated with aclidinium.

\section{DISCUSSION AND CONCLUSION}

Aclidinium is a potent and selective muscarinic antagonist with subnanomolar affinity for all receptor subtypes $\left(\mathrm{M}_{1-5}\right)$. Aclidinium dissociates, like tiotropium, more slowly from the $M_{3}$ receptor than it does from the $M_{2}$ receptor; the $\mathrm{M}_{3} \mathrm{t}_{1 / 2}$ is approximately 6 times its $\mathrm{M}_{2} \mathrm{t}_{1 / 2}$, and by that providing bronchodilatation via $\mathrm{M}_{3}$ blockage long after its less desirable $\mathrm{M}_{2}$ effects, such as tachycardia [20].

Regarding inhaled anti-muscarinic agents and risk of major cardiovascular events meta-analysis of previously published studies suggest an increased risk of cardiovascular death, myocardial infarction and stroke in COPD patients treated with inhaled anti-cholinergic drugs [12], but conclusions regarding this point awaits on-going prospective studies. However, with regard to aclidinium bromide, the clinical studies published so far have reported cardiac and vascular disorders at a similar frequency in the aclidinium and placebo groups [11], similar to what have previously been reported from other studies of long-acting antimuscarinic agents in patients with COPD $[6,12,21]$.

Aclidinium bromide is, based on the available evidence, a safe and well-tolerated long-acting anti-cholinergic bronchodilator with a relatively fast onset of action. In patients suffering from COPD, aclidinium bromide has clinically important effects on level of $\mathrm{FEV}_{1}$, health status, use of relief medication, and day-time dyspnea scores. Aclidinium bromide may have clinically important effect, with twice-daily dosing, on night-time symptom scores in COPD patients, but further studies are needed in order to permit conclusions with regard to this point.

Similar to the study by Maltais et al. [18], O'Donnell et al. [21] studied exercise endurance time in COPD patients treated with either indacaterol or placebo (mean postbronchodilator $\mathrm{FEV}_{1}$ approximately $60 \%$ pred), and reported a difference between treatment groups in exercise endurance time of $111 \mathrm{~s}$. In line with this, O'Donnell et al. [21] have also previously shown a difference between treatment groups in exercise endurance time of $105 \mathrm{~s}$ in COPD patients treated with tiotropium vs placebo (mean post-bronchodilator $\mathrm{FEV}_{1}$ $44 \%$ pred). Although the minimal important clinical difference (MCID) in duration of constant work rate cycle ergometry is not definitively established, the MCID proposed by Casaburi [22] is $105 \mathrm{~s}$. The effect of treatment with aclidinium in COPD on exercise endurance time therefore seems to at least comparable to the effect of other long-acting bronchodilators. In keeping with the study by Maltais et al. [19], studies by O'Donnell et al. [20, 21] of indacaterol and tiotropium, respectively, have previously shown an improvement in IC and IC/total lung capacity ratio, and the study by Maltais et al. [18], therefore, further supports the assumption that long-acting bronchodilators have a beneficial effect on dynamic hyperinflation in patient $\mathrm{s}$ with COPD. The treatment effect of aclidinium bromide on exercise tolerance, as assessed by exercise endurance time, and dynamic hyperinflation in patients with moderate to severe COPD seems, although based on limited evidence, to be at least comparable to other long-acting bronchodilators, incl. tiotropium bromide and indacaterol. 
Aclidinium bromide might reduce the rate of exacerbations in patients with moderate to severe COPD [10], although the ACCLAIM/COPD II study [10] did not reveal a reduction in the proportion of patients having at least one exacerbation in the group treated with aclidinium bromide. The very low proportion of patients experiencing an acute exacerbation of COPD in the ACCLAIM/COPD II is remarkable because $58 \%$ of the patients enrolled reported at least one COPD exacerbation in the year prior to inclusion in the study. Long-term controlled trials with exacerbation rate as the primary outcome variable are therefore necessary in order to further explore the effect of aclidinium bromide on COPD exacerbation rate.

In conclusion, aclidinium bromide has effects on relevant COPD outcome variables at least similar to that of other long-acting bronchodilators, including tiotropium, and therefore seems to have the potential for a significant role in the future management of moderate to severe COPD.

\section{CONFLICT OF INTEREST}

The authors confirm that this article content has no conflicts of interest.

\section{ACKNOWLEDGEMENTS}

Declared none.

\section{REFERENCES}

[1] Global strategy for the diagnosis, management, and prevention of chronic obstructive pulmonary disease. global initiative for chronic obstructive lung disease (GOLD) 2011. Available from www.gold copd.org [accessed July 2012].

[2] Celli BR, MacNee W. ATS/ERS task force. Standards for the diagnosis and treatment of patients with COPD: a summary of the ATS/ERS position paper. Eur Respir J 2004; 23: 932-46.

[3] Niewohner DE. Clinical practice: outpatients management of severe COPD. N Engl J Med 2010; 362: 1407-16.

[4] Ulrik CS. Efficacy of inhaled salmeterol in the management of smokers with chronic obstructive pulmonary disease: a single centre randomised, double blind, placebo controlled, cross-over study. Thorax 1995; 50: 750-4.

[5] Beeh KM, Wagner F, Khindri S, Drollmann AF. The effect of indacaterol on dynamic lung hyperinflation and breathlessness in hyperinflated patients with COPD. COPD 2011; 8: 340-5.

[6] Barnes PJ. The role of anticholinergics in chronic obstructive pulmonary disease. Am J Med 2004; 117: 24-32S.

[7] Hodder R. Tiotropium is superior to salmeterol in reducing frequency of exacerbations: but the effect of adding tiotropium to the combination of inhaled corticosteroid and long-acting $\beta 2$ agonist remains unclear. Evid Based Med 2012; 17: 93-5.

[8] Liberati A, Altman DG, Tetzlaff J, et al. The PRISMA statement for reporting systematic reviews and meta-analyses of studies that evaluate health care interventions: explanation and elaboration. Ann Intern Med 2009; 151: W65-94.

[9] Moher D, Liberati A, Tetzlaff J, Altman DG, for the PRISMA Group. Preferred reporting items for systematic reviews and metaanalyses: the PRISMA statement. BMJ 2009; 339: 332-6.

[10] Vestbo J, Vogelmeier C, Creemers J, Faiques M, Ribera A, Gil EG. Onset of effect of aclidinium, a novel long-acting muscarinic antagonist, in patients with COPD. COPD 2010; 7: 331-6.

[11] Jones PW, Rennard SI, Agusti A, et al. Efficacy and safety of oncedaily aclidinium in chronic obstructive pulmonary disease. Respir Res 2011; 12: 55.

[12] Singh S, Loke YK, Furberg CD. Inhaled anticholinergics and risk of major adverse cardiovascular events in patients with chronic obstructive pulmonary disease: a systematic review and metaanalysis. JAMA 2008; 300: 1439-50.

[13] Joos GF, Schelfhout VJ, Pauwels RA, et al. Bronchodilatory effects of aclidinium bromide, a long-acting muscarinic antagonist, in COPD patients. Respir Med 2010; 104: 865-72.

[14] Chanez P, Burge PS, Dahl R, Creemers J, Chuchalin A, Garcia Gil E. Aclidinium bromide provides long-acting brnchodilation in patients with COPD. Pulm Pharmacol Ther 2010; 23: 15-21.

[15] Singh D, Magnussen H, Kirsten A, et al. A randomized, placeboand active-controlled dose-finding study of aclidinium bromide administered twice-daily in COPD patients. Pulm Pharmacol Ther 2012; 25(3): 248-53.

[16] Fuhr R, Magnussen H, Sarem K, et al. Efficacy of aclidinium bromide $400 \mu \mathrm{g}$ twice daily compared with placebo and tiotropium in patients with moderate to severe COPD. Chest 2012; 141: 74552 .

[17] Kerwin EM, D’Urzo AD, Gelb AF, Lakkis H, Garcia GE, Caracta CF. Efficacy and safety of a 12 -week treatment with twice-daily aclidinium bromide in COPD patients (ACCORD COPD 1). COPD 2012; 9: 1-12.

[18] Jones PW, Singh D, Bateman ED, et al. Efficacy and safety of twice-daily aclidinium bromide in COPD patients: the ATTAIN study. Eur Respir J 2012; 40: 830-36.

[19] Maltais F, Celli B, Casaburi R, et al. Aclidinium bromide improves exercise endurance and lung hyperinflation in patients with moderate to severe COPD. Respir Med 2011; 105: 580-7.

[20] O'Donnell DE, Casaburi R, Vincken N, et al. Effect of indacaterol on exercise endurance time and lung hyperinflation in COPD. Respir Med 2011; 105: 1030-6.

[21] O'Donnell DE, Fluge T, Gerken F, et al. Effects of tiotropium on lung hyperinflation, dyspnea and exercise tolerance in COPD. Eur Respir J 2004; 23: 832-40.

[22] Casaburi R. Factors determining constant work rate exercise tolerance in COPD and their role in dictating the minimal clinically important difference in response to interventions. COPD 2005; 2 : $131-6$. 